\title{
Older workers from the viewpoint of their younger colleagues. Do organisations fail to harness the potential of an ageing workforce?
}

\author{
Tanja Kosowski
}

\begin{tabular}{|c|c|}
\hline \multicolumn{2}{|r|}{ A B S T R A C T } \\
\hline \multicolumn{2}{|c|}{$\begin{array}{l}\text { Objective: Scholars agree that due to an ageing workforce which is observable in many } \\
\text { societies around the globe, organisations will face an employee base that is getting } \\
\text { older and more age-diverse (Kunze et al., 2011). This development can be beneficial for } \\
\text { organisations when its potential gets harnessed; however, it leaves us also with some } \\
\text { concerns. Research studies found rather unpromising results for an ageing workforce } \\
\text { in the organisation. This article sheds light on the perception of older employees from } \\
\text { the perspective of their younger co-workers, where little is known about. }\end{array}$} \\
\hline \multicolumn{2}{|c|}{$\begin{array}{l}\text { Research Design \& Methods: It uses a qualitative study design through in-depth in } \\
\text { terviewing and metaphorical talk. In total, } 27 \text { interviews have been collected in Ger- } \\
\text { many and Poland. }\end{array}$} \\
\hline \multicolumn{2}{|c|}{$\begin{array}{l}\text { Findings: Respondents point out that their senior colleague possesses crucial human } \\
\text { and social capital for the organisation. They further reveal obstacles which partially ex- } \\
\text { plain, why results from previous studies may vary. }\end{array}$} \\
\hline \multicolumn{2}{|c|}{$\begin{array}{l}\text { Contribution \& Value Added: The perception of younger employees offers valuable in- } \\
\text { side for employers and entrepreneurs alike. Employers have been found to have a } \\
\text { somewhat negative attitudes towards the employability of senior-aged workers. } \\
\text { Younger employees revealed that senior-aged workers are perceived to have a vital } \\
\text { role in knowledge transfer by their younger colleagues. }\end{array}$} \\
\hline Article type: & \\
\hline & \\
\hline & $J I 1, J 14, I V I \perp 2$ \\
\hline \\
\hline
\end{tabular}

\section{Suggested citation:}

Kosowski, T. (2020). Older workers from the viewpoint of their younger col-leagues. Do organisations fail to harness the potential of an ageing workforce?. International Entrepreneurship Review (previously published as International Entrepreneurship / Przedsiębiorczość Międzynarodowa), 6(2), 8394. https://doi.org/10.15678/IER.2020.0602.06 


\section{INTRODUCTION}

The ageing of the population is identified as a grand global issue (Barkema et al., 2015; George et al., 2016). Under an ageing workforce, scholars understand an increase of high aged employees in the organisation, plus a more age-diverse employee base (Stankiewicz, 2015). A first concern is the strong presence of people belonging to the baby boomer generation in the workforce (Van Bavel \& Reher, 2013). A second concern is an observation that fewer people enter the workforce in comparison to older people active in the workforce. The latter one results from corresponding trends which are evident in many societies around the world (e.g. decreasing fertility rate, increasing life expectancy, delayed entrance in the labour market owed to higher education, better access to health systems and increasing health conditions in high ages) (van Dalen et al., 2009).

Consequently, companies are commonly confronted with the fact that their workforce is getting older and more age-diverse (Kunze et al., 2011). One may ask why this observation is a grand challenge. Unfortunately, research indicates prevailing negative attitudes against older workers among managers (Turek \& Perek-Białas, 2013), and employees alike (Finkelstein et al., 2013). In result, older workers experience negative consequences, such as age discrimination (Patel et al., 2018). Moreover, the results of studies undertaken on an increasing age diversity within the organisation are not too promising, at best mixed (Kunisch et al., 2011; Kunze et al., 2011). Negative attitudes, plus unpromising results from the field of age diversity management, could provoke counterproductive management decisions, recruitment decisions or human resource management decisions. Overall, it could have negative consequences concerning the employability of senior workers in organisations.

This study wants to contribute to the literature in two ways. It aims to shed light on the perception of older workers from the viewpoint of their younger colleagues, where little is known about (Patel et al., 2018). Older workers are often described to possess a higher degree of expertise in comparison to their younger colleagues (van Dalen et al., 2009). Hence, they are believed to have a focal role in generating social capital (Rabl \& Triana, 2013). Second, it wants to understand the role of older workers within the organisation from the viewpoint of younger co-workers. Therefore, a qualitative study design was used to shed light on the perception of younger workers through metaphorical talk.

\section{LITERATURE REVIEW AND THEORY DEVELOPMENT}

\section{Age diversity in the organization}

As shown in literature, age diversity has a dual nature, exhibiting positive and negative effects (Kunze et al., 2011). There is an ongoing debate concerning age diversity in general or the effects of age-diversity for the organisation. A well-supported stream in diversity researcher literature follows the similarity-attraction paradigm. Here, the adverse effects of age diversity get outlined. The assumption of similarity can be drawn from various surface-level diversity attributes, as demographics (e. g. age, gender, ethnicity) or deep-level diversity attributes (e. g. attitudes, beliefs. Social identity theory (Tajfel, 1978) and social categorisation theory (Turner, 1982) have been used to describe that individuals define themselves over their group memberships. The rational of these theories suggest that people categorise others based on similarities and dissimilarities (Mohammed \& Angell, 
2004; Tajfel \& Turner, 1986). In result, individuals tend to favour their group (in-group) at the cost of others (out-group), against which they tend to discriminate (Turner, 1982). There is vast support in the literature that age serves as a criterion based on which formation and categorisation processes can take place (Kearney \& Gebert, 2009).

Diversity research outlining the positive effects of age diversity belongs to the information/decision-making perspective' (van Knippenberg \& Schippers, 2006). Important here is the information richness, resulting from the heterogeneity of team members. The heterogeneity can likewise be caused by surface- and deep-level diversity. Heterogeneity of group members benefits from complementing information, knowledge and experiences (Beckman $\&$ Haunschild, 2002). Within this stream, social capital theory and human capital theory are used to explain why diverse groups are often found to perform better than heterogenous groups (Rabl \& Triana, 2013). Scholars mainly base their arguments on the information-richness and access to a wide range of capabilities and networks. (Gerpott et al., 2017). Heterogeneity seems to be especially useful when facing non-standard problems (Carpenter, 2002). While human capital stands for the uniqueness of a person's experiences, skills, knowledge, abilities and expertise, gained throughout life (Becker, 1964), social capital describes the value of an individual's network for the organisation (Tasheva \& Hillman, 2019).

In conclusion, the whole diversity research field made use of two main theoretical perspectives. While the similarity-attraction paradigm explains possible adverse outcomes of diversity, information/decision making perspective argues for the positive effects of diversity within organisations (van Knippenberg \& Schippers, 2006). Overall, employers have a crucial role in handling an ageing workforce. They need to manage age diversity effectively within their organisations. Likewise, in the light of a potential skill shortage, they need to retain and recruit senior employees (Sousa \& Ramos, 2019; von Bonsdorff et al., 2018). Asking about employers' perception of an ageing workforce, increased age diversity and an increased number of senior employees in the workforce results so far are not too promising (Stypinska \& Turek, 2017; Turek \& Perek-Białas, 2013; Van Dalen et al., 2015). From the viewpoint of employers, individual productivity of their employees plays a vital role in their assessment. Unfortunately, higher age often gets associated with a decline in individual productivity (Goštautaitė \& Bučiūnienè, 2015). Having lower productivity compared to younger aged individuals is one of the most common age-biases, senior-aged employees have to face in the workplace. Although, up to date, studies are failing to prove that higher age and lower productivity are related (Costanza \& Finkelstein, 2015). On the other hand, studies conducted among employers have frequently evidenced that employers associate senior-aged employees with lower productivity (Conen et al., 2012; Turek \& Perek-Białas, 2013). As found by Van Dalen and colleagues, the perceived "productivity gap" affects the recruitment and retention of senior individuals in the organisation (Conen, van Dalen and Henkens, 2012, p. 641).

\section{Senior-aged employees in the organisation}

Studies on age diversity, in particular, the groups of senior-aged workers are carried out by using different research samples (employers/managers, senior workers or co-workers (young and mid-aged)). Exemplary literature for studies carried out using the managers' or employers' perspective constitute a significant part in the up-to-date literature (Conen et al., 2012; Rego et al., 2017). A vast majority of studies also pertains to the perception of senior-aged individuals, reflecting their self-perception (Kraak et al., 2018; Taneva et al., 2014). Fewer studies are focusing on the perception of co-workers (Patel et al., 2018). 
However, considering an ageing workforce and an increase in senior individuals within the organisation, it becomes more critical that different aged individuals can work together effectively. One of the few studies which considered the viewpoint of younger employees, brought to light a rather negative attitude concerning the physical capability, productivity, use of technology and acceptance of change (Brooke \& Taylor, 2005; Cadiz et al., 2015). Such studies have, however, been carried out quantitatively and provide no insights. The main objective of the presented study is, therefore, to provide such insight with the help of metaphorical talk and in-depth interviewing.

\section{MATERIAL AND METHODS}

\section{Methodology}

The research is exploratory. It seeks to generate a more detailed view of the perceived role of senior workers from the viewpoint of younger co-workers. An extensive body of literature sheds light on senior workers in the organisation from the viewpoint of employers (Turek \& Perek-Białas, 2013). Employees perceptions, in general, are rather underrepresented. We know only little about the younger employee's perception.

Since the aim is to explore perceptions of older workers in the organisation from the viewpoint of their younger co-workers, an interpretative research approach was adopted. The main research question guiding the study is: How do younger employees perceive their senior-aged co-workers. Younger employees have been asked to describe a senioraged colleague with a metaphor. The openness of the qualitative method used facilitates data collection that is not constrained by categories of analysis that are predetermined and therefore allows for more depth and detail than a quantitative methodology.

The research question was explored in the German and Polish context. The data presented in this article are preliminary findings to a more extensive study on working in age-mixed teams in both countries. Considering both contexts together is reasonable, as Germany and Poland share essential cultural and institutional commonalities. Both are members of the European Union; they are neighbours and have geographical and economic closeness. However, they also have specific differences. Germany currently presents a participation rate of senior employees above the EU-average, while at the same time it is one of the oldest countries in Europe. On the other hand, Poland currently counts to the youngest countries in the European Union, with a participation rate of senior workers below the EU-average (European Commission, 2018). Taking both countries together allows drawing conclusion based on two different contexts (high participation rate of senior workers, and low participation rate of senior workers) which may facilitate to reflect reality in a better way. In total, 27 in-depth interviews have been collected among younger employees (employees aged 20-35 years).

A total of 15 interviews was collected in Germany, while 12 interviews have been conducted in Poland. All respondents have been knowledge workers within the service sector. Interview participants worked as engineers, sales engineers, accountants or consultants. Jobs in the service sector show an often higher degree of social interaction and collaboration, which seems to be crucial for the investigation of the research questions (Göbel \& Zwick, 2012). Although the service sector was chosen as an exemplary industry, finance, information technology (IT) and insurance companies have not been considered. Research 
proofed that these genres demonstrate to have high stereotyping behaviour (Posthuma \& Campion, 2009). As the research does not aim to expose stereotypes about older age groups, they have been avoided.

At the outset of the research, the project the author sampled for service organisations using platforms such as Kununu, Staufenbibel, Linkedin, Xing and own contacts. After five organisations declared their initial consent to participate in the research, the interview process started. The organisations, as well as the interview participants, helped to locate further participants within the organisation or outside. In the end, 12 service organisations in Germany and Poland contributed to the research project. All interviews were conducted on-site, recorded with the consent of the participant, and transcribed verbatim. The analysis involved a two-cycle coding process. During the first cycle, initial coding was used. Focused coding was performed during the second coding cycle. Hence, a combination of theoretical and convenience sampling was used to inform the research study.

All interviews were conducted on-site in the native language of the interview participants (German) or English. The interviews were transcribed, coded, and analysed using MAXQDA software. After the analysis, only selected excerpts were translated from German to the English language in a subsequent step. An interviewer guideline helped to ensure comparability between interviews but left enough room to allow for a more in-depth discussion of emerging issues. The openness allowed for a broader analysis of held perceptions and considered the internal burden of participants to talk about their perceptions and colleagues. Interviews ranged from 41-180 minutes and were recorded and anonymised during the transcription process.

The transcripts have been coded for references to perceptions of younger workers about their senior colleagues. Using open coding (Strauss \& Corbin, 1998), a record of every kind of metaphor was kept in the participants' words, and constant comparative analysis was then used to aggregate metaphors into broader themes. Metaphors are an outcome of the cognitive processes of individuals. Metaphorical images comprise our way of thinking and reveal the connotation of words and the language we use. Hence, there is power in metaphors to structure our thoughts and present the essence of a topic (Latusek \& Vlaar, 2015). I am aware that such a qualitative study, using metaphors of respondents may have its limitations. The qualitative methodology used may not allow for generalisability of the presented results with the same certainty as a quantitative study could. Especially, as qualitative studies must be closely interpreted in the context in which they have been performed. Further, respondents may have been influenced by their own stereotypical beliefs. However, it may provide a unique and in-depth understanding of the perception younger employees shape about their senior co-workers which was the main goal of the presented study. The metaphorical analysis revealed that younger respondents identified three major key themes when talking about a senior colleague. Metaphors used to describe an older colleague were mainly, network-related images, wisdom-related images, and scarcity-related images. Each of the key themes is elaborated below.

\section{Empirical findings}

\section{Network related images}

Network related images have been used to refer to two different kinds of network. Either respondents referred to the internal network of their senior colleagues (e.g. co-workers, 
managers, owner) or the metaphor was used to point towards the external network (e.g. business partners, employees of competitors, clients) of their senior co-worker. For references to the internal network, interview respondents recognised that their senior workers have a well-developed network within the organisation. Senior colleagues have contacts to members of different teams, department, or units within the organisation. They also recognised that senior workers have contact with persons from different management levels.

My colleague here is a bit like in the lion king. But Scar and Mufasa are two completely different characters. They are also two different persons, and he often disagrees with our boss. They work together for so many years, they are friends, and our boss appreciates his opinion. Maybe Zazu would fit better in that case, yes he is like Zazu. He is always the one to inform our boss.

Younger colleagues value the strong internal network as it would help them to push their interests. Their senior co-workers would be able to refer them to a person who can help with internal issues. Further, some interview respondents mentioned that a strong relationship between their senior colleague and their manager would be profitable for them. In some cases, the senior colleague, therefore, addresses topics which other younger team members would be afraid of addressing.

Concerning the external network, respondents likewise outlined connections within the industry or to competitors, as well as a network of clients and business partners. Such strong ties outside the organisation can be profitable in many ways. Maintaining contacts within the industry or to competitors would help senior colleagues to get information from other organisations. The external network of senior colleagues was further mentioned as helpful when younger employees want to consider new possibilities outside their current organisation (e.g. job change).

The older ones are a bit like farmers. They work on the basis of relationships and loyalty. They can harvest each relationship. That is very much like a farmer; they can harvest their relations. They work together with this person for years, and now they just need to harvest the seed they planted many years ago.

\section{Wisdom-related images}

When using a wisdom-related image, respondents either talked about job experience, life experience, knowledge about the organisation or knowledge about the industry. Words, such as "wisdom", "know-how" or "expertise" often have been used interchangeably. Other than knowledge related to the job, they also outline "career advice" and "life advice" as general guidance they receive from senior-aged colleagues. Therefore, respondents using such a metaphor wanted to outline a combination of substantial knowledge in the job, plus an equally substantial amount of life experience.

It is a bit like Gandalf. He is this powerful, good wizard from Lord of the Rings. He has the knowledge about witchcraft and secrets-, he is a good advisor for general life troubles too.

Most respondents using these metaphors also refer to specific hierarchical differences younger respondents perceive between them and their senior colleagues. Almost all used metaphors pictured the senior worker in a kind of authority position, while the younger 
respondent pictured themselves in a non-authority position. The hierarchy gets established by a different knowledge base. While considering themselves as having knowledge gaps, they describe their senior colleagues as knowledge-rich. Respondents, therefore, agree that they can learn a lot from their senior colleagues, but do not see much knowledge they could offer in return. That knowledge difference creates a feeling of respect towards their older colleagues.

A would say a king-, or a superhero. Something in this direction. Someone you look up to. They usually do not make any errors. Well, I have great respect for them, because I can learn so much. There are so many things I need to catch up, and I hope I will get a chance.

Wisdom related images also have been used to describe a rather one-directional knowledge transfer between the younger employee and their senior colleague. Within their relationships, the senior colleagues would have the role of a kind of mentor or teacher, whereas the younger employee would represent the mentee or student. Knowledge within this relationship flows from the senior colleague to the younger colleague.

The old Jedi master and the young padawan, and the old Jedi master guides the young padawan. But I think that describes it well. The old Jedi master who has gathered experience and the young one who needs to be guided a bit.

In sum, these metaphors have been chosen to picture the knowledge base of senior colleagues. The used metaphors described a perceived hierarchical difference between the senior colleagues and the younger colleague. The rich knowledge base, plus the perceived hierarchical difference manifested in a feeling of respect what younger colleagues described to have towards their senior co-worker. Knowledge transfer is a central part of these metaphors, where knowledge would flow from the senior worker to the younger worker. Knowledge in their description related to job-relevant knowledge, but also knowledge about work and life in general.

\section{Scarcity related images}

Using metaphors to describe the isolation, respondents referred to senior workers as a minority within the organisation. Metaphors have been used from movies, cartoons, a particular profession, or from animals. All the metaphors pictured either a figure which leads a withdrawn life or a kind of endangered animal. Respondents using such a metaphor wanted to describe a lack of peers for senior workers in their organisation. Moreover, they wanted to point out that senior workers in their organisation are somewhat underrepresented in the staff base.

I would say senior workers are-, a bit chameleon-like in our organisation. They are extremely rare, I mean-, I think a few are working here, but only a few. I have one in my team, and I know of three or four others, but that is it, I think there are some more, but only one or two hands full. That makes them even more chameleon-like if you happen to see one than rather only one. You really must watch out for them.

The described scarcity is not problematic itself, as explained by the younger respondents. However, they perceive that since sometimes they are the only aged person among a group of younger colleagues, they self-isolate themselves further. 
Probably, yeah, there is, probably he is not looking quite like Shrek, but then Shrek was not old, but he was sort of alone, living in the woods, aside from other people. And there were not many Shrek-like persons around, there was just Fiona also, but that was about it. And I think it is like this with Mr. xxx. He is a likeable person, likeable, but then he has nobody to talk to. You know what I mean, someone with similar interests, similar age. I think we are just too young for him.

\section{CONCLUSIONS}

It can be concluded from the metaphorical descriptions that younger respondents agree that their senior colleagues have valuable social capital for the organisation. The social capital for older workers consist of a vital internal (e.g. other members of the organisation, management members of the organisation) network and external network (e.g. clients, potential clients, business partners, former clients, members of other organisations), This social capital can be profitable for the organisation. However, some respondents also described situations in which this social capital may exert adverse consequences for the organisation (e.g. helping qualified colleagues to change to another organisation), as it can be used to help talented workers to find a position outside the organisation.

Much of the wisdom-related images, pictured the strong knowledge base of senior worker and would most probably suit to what is referred to in the literature as human capital (D’Netto et al., 2014; Tasheva \& Hillman, 2019). The knowledge described by younger respondents comprised different sorts of knowledge. There are qualitative differences among respondents. Some describe rather hard facts, such as sector knowledge, technical or product knowledge and usually referred to 'expert' or 'expert knowledge'. On the other hand, others refereed to relatively soft sorts of knowledge, such as the knowledge about different methods, practical application of knowledge or codes of conduct and have been somewhat tempted to talk about 'experience' or 'expertise'.

Respondents in majority outline a classic transfer of knowledge in which knowledge flows from the senior colleague to the younger colleague. However, nowadays also, the reversed pattern could be of increased interest. As younger colleagues often feel great respect and little self-confidence towards their knowledge, younger co-workers could be discouraged or restraint to share their knowledge with their senior co-worker. In consequence, it may have a negative consequence for complementing knowledge which is said to be one of the significant benefits of having people of different age groups working together. People of different ages, especially younger employees, maybe constraint from sharing their knowledge. This may at least partially explain why not all investigated agediverse groups succeed to harness their full human capital potential.

Scarcity-related images pictures senior workers as rather seldom and unique in the organisation. A lack of peers and a substantial visible minority of a particular age group within the organisation may create tokenism like environments for senior colleagues which in return could be detrimental for the motivation and well-being of senior colleagues in the organisation (Zimmer, 1988). Further, it provides a ground for age discrimination within the organisation (Comer et al., 1998). Future research may want to distinguish between actual and perceived age discrimination of older workers. Some qualitative studies may also want to shed light on possible personal and interactional consequences for senior workers in strong age-dissimilar groups (extreme young groups). 
The presented point out obstacles which could explain why harnessing the potential of a diverse age workforce gets hampered. Senior workers are of importance to the organisation as they possess relevant human and social capital. In line with the literature, possessing a diverse range of human and social capital does not always have to be automatically beneficial for the organisation (Kunze et al., 2011). Harnessing the potential of human capital can also become hampered when members of other age groups are restrained from knowledge sharing possibilities, due to a predominant classic model of knowledge transfer, or feelings of inferiority. Social capital may become a disadvantage by missing development opportunities within the organisation. Lastly, the research brought to light that senior workers in the organisation are firmly underrepresented, which may bear the risk of creating tokenism-like environments that foster ageism in the workplace.

In summary, the presented study contributes to the literature in two ways. Firstly, it provides insight into the perception of the role of senior workers within the organisation from the viewpoint of young employees. Younger respondents perceived that their senioraged co-workers are focal for an organisation's human capital, have a crucial role in knowledge transfer within the organisation, as well as they are important in the creation of social capital. Future research may have a closer look at the types of knowledge which are passed on from senior to younger colleagues, to gain a subtler understanding of the knowledge sharing process. What is more, within this study, young employees have been defined as individuals aged a minimum of 20 years, up to 35 years. Future research may wish to consider individuals belonging to Generation $Z$ and individuals belonging to Generation $Y$ separately. Secondly, employer opinions and opinions of company owner have, so far, reflected a rather negative attitude towards an increasing number of senior employees in the workforce. The presented brings to light positive aspects of an increasing number of senior workers in the workforce and outlines their focal role in knowledge transfer and the creating of social capital. Employers and entrepreneurs alike need to be aware of its positive aspects in other to potentially harness the potential benefits of increasing age diversity and an increasing number of senior employees in the organisation, to avoid counterproductive management decisions.

\section{REFERENCES}

Barkema, H.G., Chen, X., George, G., Luo, Y., \& Tsui, A.S. (2015). West Meets East : New Concepts and Theories. Academy of Management Journal, 58(2), 460-479. https://doi.org/10.5465/amj.2015.4021 WEST

Becker, G. (1964). Human Capital. Columbia University Press.

Beckman, C.M., \& Haunschild, P.R. (2002). Network Learning: The Effects of Partners' Heterogeneity of Experience on Corporate Acquisitions. Administrative Science Quaterly, 47(1), 92-124. https://doi.org/10.2307/3094892

Brooke, L., \& Taylor, P. (2005). Older workers and employment: Managing age relations. Ageing and Society, 25(3), 415-429. https://doi.org/10.1017/S0144686X05003466

Cadiz, D.M., Truxillo, D.M., \& Fraccaroli, F. (2015). What are the benefits of focusing on generationbased differences and at what cost? Industrial and Organizational Psychology, 8(3), 356-362. https://doi.org/10.1017/iop.2015.49

Carpenter, S.R. (2002). Ecological futures: Building an ecology of the long now. Ecology, 83(8), 20692083. https://doi.org/10.1890/0012-9658(2002)083[2069:EFBAEO]2.0.CO;2 
Comer, L.B., Nicholls, J.A.F., \& Vermillion, L.J. (1998). Diversity in the sales force: Problems and challenges. Journal of Personal Selling and Sales Management, 18(4), 1-20. https://doi.org/10.1080/08853134.1998.10754145

Conen, W.S., van Dalen, H.P., \& Henkens, K. (2012). Ageing and employers' perceptions of labour costs and productivity: A survey among European employers. International Journal of Manpower, 33(6), 629-647. https://doi.org/10.1108/01437721211261796

Costanza, D.P., \& Finkelstein, L.M. (2015). Generationally based differences in the workplace: Is there a there there? Industrial and Organizational Psychology, 8(3), 308-323. https://doi.org/10.1017/iop.2015.15

D’Netto, B., Shen, J., Chelliah, J., \& Monga, M. (2014). Human resource diversity management practices in the Australian manufacturing sector. International Journal of Human Resource Management, 25(9), 1243-1266. https://doi.org/10.1080/09585192.2013.826714

European Commission. (2018). The 2018 Ageing Report: economic and budgetary projections for the EU Member States (2016-2070). European Economy, 2, Issue May). https://doi.org/10.2765/615631

Finkelstein, L.M., Ryan, K.M., \& King, E.B. (2013). What do the young (old) people think of me? Content and accuracy of age-based metastereotypes. European Journal of Work and Organizational Psychology, 22(6), 633-657. https://doi.org/10.1080/1359432X.2012.673279

George, G., Howard-Grenville, J., Joshi, A., \& Tihanyi, L. (2016). Understanding and tackling societal grand challenges through management research. Academy of Management Journal, 59(6), 1880-1895. https://doi.org/10.5465/amj.2016.4007

Gerpott, F.H., Lehmann-Willenbrock, N., \& Voelpel, S.C. (2017). A phase model of intergenerational learning in organizations. Academy of Management Learning and Education, 16(2), 193-216. https://doi.org/10.5465/amle.2015.0185

Göbel, C., \& Zwick, T. (2012). Age and Productivity: Sector Differences. Economist, 160(1), 35-57. https://doi.org/10.1007/s10645-011-9173-6

Goštautaitè, B., \& Bučiūnienè, I. (2015). The role of work characteristics in enhancing older employees' performance: evidence from a post-Soviet country. International Journal of Human Resource Management, 26(6), 757-782. https://doi.org/10.1080/09585192.2014.949820

Kearney, E., \& Gebert, D. (2009). Managing Diversity and Enhancing Team Outcomes : The Promise of Managing Diversity and Enhancing Team Outcomes: The Promise of Transformational Leadership. Journal of Applied Psychology, 94(1), 77-89. https://doi.org/10.1037/a0013077

Kraak, J.M., Russo, M., \& Jiménez, A. (2018). Work-life balance psychological contract perceptions for older workers. Personnel Review, 47(6), 1198-1214. https://doi.org/10.1108/PR-10-2017-0300

Kunisch, S., Boehm, S.A., \& Boppel, M. (2011). From grey to silver: Managing the demographic change successfully. From Grey to Silver: Managing the Demographic Change Successfully, March 2015, 1-223. https://doi.org/10.1007/978-3-642-15594-9

Kunze, F., Boehm, S.A., \& Bruch, H. (2011). Age diversity, age discrimination climate and performance consequences - a cross organizational study. Journal of Organizational Behavior, 32, 264-290. https://doi.org/10.1002/job.698

Latusek, D., \& Vlaar, P.W.L. (2015). Exploring managerial talk through metaphor: An opportunity to bridge rigour and relevance? Management Learning, 46(2), 211-232. https://doi.org/10.1177/1350507614529512

Mohammed, S., \& Angell, L.C. (2004). Surface- and deep-level diversity in workgroups: Examining the moderating effects of team orientation and team process on relationship conflict. Journal of Organizational Behavior, 25(8), 1015-1039. https://doi.org/10.1002/job.293 
Patel, J., Tinker, A., \& Corna, L. (2018). Younger workers' attitudes and perceptions towards older colleagues. Working with Older People, 22(3), 129-138. https://doi.org/10.1108/WWOP-022018-0004

Posthuma, R.A., \& Campion, M.A. (2009). Age stereotypes in the workplace: Common stereotypes, moderators, and future research directions. Journal of Management, 35(1), 158-188. https://doi.org/10.1177/0149206308318617

Rabl, T., \& Triana, M. (2013). How German employees of different ages conserve resources: Perceived age discrimination and affective organizational commitment. International Journal of Human Resource Management, 24(19), 3599-3612. https://doi.org/10.1080/09585192.2013.777936

Rego, A., Vitória, A., Ribeiro, T., Ribeiro, L., Lourenço, R., Leal, S., \& Pina, M. (2017). Attitudes and HRM decisions toward older workers in Africa: Exploring contradictions through an empirical study. European Management Review, 1-28. https://doi.org/10.1080/09585192.2019.1710720

Sousa, I., \& Ramos, S. (2019). Longer working lives and age diversity: A new challenge to HRM. European Journal of Management Studies, 24(1), 21. https://doi.org/10.5455/ejms/288677/2019

Stankiewicz, K. (2015). Value of Age Diversity - Declarations and Practice in Polish Organizations. Social Sciences, 89(3), 19-32. https://doi.org/10.5755/j01.ss.89.3.13670

Strauss, A., \& Corbin, J. (1998). Basics of Qualitative Research: Techniques and Procedures for Developing Grounded Theory. SAGE Publications, Inc.

Stypinska, J., \& Turek, K. (2017). Hard and soft age discrimination : the dual nature of workplace discrimination. European Journal of Ageing, 14(1), 49-61. https://doi.org/10.1007/s10433016-0407-y

Tajfel, H. (1978). Differentiation between social groups: studies in the social psychology of intergroup relations (1st ed.). Academic Press.

Tajfel, H., \& Turner, J.C. (1986). The social identity theory of intergroup behavior (Eds). Nelson-Hall.

Taneva, S., Arnold, J., \& Nicolson, R. (2014). A qualitative analysis of older workers' perceptions of stereotypes, successful ageing strategies and human resource management practices. In VII National Congress of Psychology, Sofia, Bulgaria.

Tasheva, S., \& Hillman, A.J. (2019). Integrating diversity at different levels: multi-level human capital, social capital, and demographic diversity and their implications for team effectiveness. Academy of Management Review, 44(4), 746-765. https://doi.org/10.5465/amr.2015.0396

Turek, K., \& Perek-Białas, J. (2013). The role of employers opinions about skills and productivity of older workers: example of Poland. Employee Relations, 35(6), 648-664. https://doi.org/10.1108/ER-04-2013-0039

Turner, J.C. (1982). Toward a cognitive definition of the group. In H. Tajfel (Ed.), Social identity and intergroup relations. (1st ed., pp. 15-40). Cambridge University Press.

Van Bavel, J., \& Reher, D.S. (2013). The baby boom and its causes: What we know and what we need to know. Population and Development Review, 39(2), 257-288. https://doi.org/10.1111/j.17284457.2013.00591.x

van Dalen, H.P., Henkens, K., \& Schippers, J. (2009). Dealing with older workers in Europe: A comparative survey of employers' attitudes and actions. Journal of European Social Policy, 19(1), 47-60. https://doi.org/10.1177/0958928708098523

Van Dalen, H.P., Henkens, K., \& Wang, M. (2015). Recharging or retiring older workers? Uncovering the age-based strategies of european employers. Gerontologist, 55(5), 814-824. https://doi.org/10.1093/geront/gnu048

van Knippenberg, D., \& Schippers, M.C. (2006). Work Group Diversity. Annual Review of Psychology, 58, 515-541. https://doi.org/10.1146/annurev.psych.58.110405.085546 
von Bonsdorff, M.E., Zhou, L., Wang, M., Vanhala, S., von Bonsdorff, M.B., \& Rantanen, T. (2018). Employee Age and Company Performance: An Integrated Model of Aging and Human Resource Management Practices. Journal of Management, 44(8), 3124-3150. https://doi.org/10.1177/0149206316662314

Zimmer, L. (1988). Tokenism and Women in the Workplace : The Limits of Gender-Neutral Theory Problems Linked references are available on JSTOR for this article : Tokenism and Women in the Workplace : The Limits of Gender-Neutral Theory *. Social Problems, 35(1), 64-77.

\section{Author}

\section{Tanja Kosowski, MA}

Bachelor of Business Administration (DHBW Ravensburg, Germany); Bachelor of Business Administration (University of South Wales, UK); Master in International Relations (University of Lodz, Poland); PhD student Management (Kozminski University, Poland). His research interests include diversity management, human resource management, and ageism.

Correspondence to: Tanja Kosowski, MA, Kozminski University, Department of Management, ul. Jagiellońska 57/59, 03-301 Warsaw, Poland, email: tkosowski@kozminski.edu.pl

ORCID (1) http://orcid.org/0000-0002-0281-4310

\section{Acknowledgements and Financial Disclosure}

The author would like to thank the anonymous referees for their useful comments, which allowed to increase the value of this article.

\section{Copyright and License}

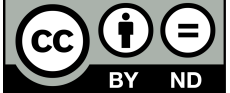

This article is published under the terms of the Creative Commons

Attribution - NoDerivs (CC BY-ND 4.0) License

http://creativecommons.org/licenses/by-nd/4.0/

Published by the Centre for Strategic and International Entrepreneurship - Krakow, Poland

The journal is co-financed in the years $2019-2020$ by the Ministry of Science and Higher Education of the Republic of Poland in the framework of ministerial programme "Support for Scientific Journals" (WCN) on the basis of contract no. 238/WCN/2019/1 concluded on 15 August 2019. 